A Program Evaluation Study of the Main Course at a Preparatory Program:

A Case Study

Turkish Online Journal of Qualitative Inquiry (TOJQI)

Volume 9, Issue 3, July 2018: 202-239 / Cilt 9, Sayı 3, Temmuz 2018: 202-239

DOI: $10.17569 /$ tojqi.426886

Research Article / Araştırma Makalesi

\title{
A Program Evaluation Study of the Main Course at a Preparatory Program: \\ A Case Study
}

Gülçin Mutlu ${ }^{1}$

\begin{abstract}
This study is an evaluation case study and aims to evaluate the English as a foreign language (EFL) preparatory course called Main Course (MC) on the basis of the modified version of Bellon and Handler's (1982) evaluation model. The purpose of this study is twofold: i) analyze the EFL preparatory course with regard to its four fundamental aspects, a) aims and objectives, b) course content and materials, c) course conduct and d) student assessment and outcomes, and ii) identify aspects to be improved in relation to these four areas. The participants of the study included the course instructors and their students in several preparatory classrooms. The study followed a mixed methods design in which the data were collected through questionnaires, interviews and observations. The results revealed that $\mathrm{MC}$ was generally effective with regard to the four fundamental aspects as reported by the course instructors and students. The qualitative and quantitative data used to identify the gaps between the current and expected situation of the course in terms of four aspects corroborated to a large extent. However, the results showed inconsistencies between teachers' and students' perceptions especially in terms of the aspects of course content and assessment. For the improvement of the gaps found as a result of the evaluation activities, several recommendations were made such as the inclusion of more practice activities and various types of assessment methods to test student performance in the course and consideration of alignment between the testing and teaching procedures.
\end{abstract}

Keywords: Program evaluation, curriculum evaluation, English course evaluation.

\footnotetext{
${ }^{1}$ Asst.Prof.Dr., Izmir Demokrasi University, Faculty of Education, Department of Educational Sciences, gulcin.mutlu@idu.edu.tr, https://orcid.org/0000-0002-0996-9104
}

Received: 24.05.2018 Accepted: 30.05.2018 


\title{
Hazırlık Programı Temel Dersinin Program Değerlendirme Çalışması:
}

\section{Bir Durum Çalışması}

\begin{abstract}
$\ddot{\mathbf{O} z}$
$\mathrm{Bu}$ çalışma bir program değerlendirme durum çalışmasıdır ve bir yabancı dil olarak İngilizce hazırlık programındaki Temel dersin (TD) Bellon ve Handler'ın (1982) değerlendirme modelinin adapte edilmiş hali ile değerlendirilmesini amaçlamaktadır. Çalışmanın amaçları iki şekilde özetlenebilir: i) yabancı dil olarak İngilizce hazırlık programındaki Temel dersinin a) dersin hedefleri ve amaçlar, b) ders içeriği ve materyaller, c) dersin işlenişi ve d) öğrenci değerlendirmesi ve sonuçlar olmak üzere bir dersi oluşturan dört ana öğeye göre değerlendirilmesi ve ii) bu dört temel öğe itibari ile iyileştirilmesi gereken yönlerin belirlenmesi. Çalışma örneklemini hazırlık sınıfının farklı sınıflarında öğrenim gören öğrenciler ve ders öğretim elemanları oluşturmaktadır. Bir karma desen çalışması olan bu değerlendirme çalışmasında veriler anket, görüşme ve yapılan gözlemler aracılığıyla toplanmıştır. Çalışma sonuçları İngilizce Temel dersinin öğrenci ve öğretim elemanları görüşlerine göre bir dersi oluşturan dört temel öğe açısından bakıldığında genel olarak etkili olduğunu göstermiştir. Bu dört temel öğeye göre var olan ve olması istenen durum arasındaki fark1 tespit etmek için kullanılan nitel ve nicel verilerin büyük ölçüde örtüştügü görülmüştür. Fakat sonuçlar özellikle dersin içeriği ve öğrenci değerlendirmesi öğelerinde öğretmen ve öğrenci görüşleri arasında tutarsızlıkların var olduğunu da göstermektedir. Değerlendirme etkinlikleri sonucunda tespit edilen iyileştirilmesi gereken alanlar için öğrenci pratiğine daha fazla imkân veren etkinliklere yer verilmesi, öğrenci performansını ölçmek için farklı ve çeşitli değerlendirme yöntemlerinin derse dahil edilmesi ve öğretim ile değerlendirme öğeleri arasındaki uyuma dikkat edilmesi gibi tavsiyelerde bulunulmuştur:
\end{abstract}

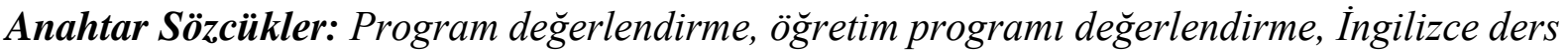
değerlendirme. 
A Program Evaluation Study of the Main Course at a Preparatory Program:

A Case Study

\section{Introduction}

The recent demands as institutional accreditation, accountability testing, outcomes assessment, quality assurance and control in the global and our local language education agendas resulted in a growing surge of interest and awareness of program evaluation by the language educators (Norris, 2009) as an important vehicle in bringing about some important results and implications for the standardization and improvement of the programs. Program evaluation refers to serious and comprehensive investigation of any system or innovation for the purposes of improving conditions and providing richer educational opportunities and experiences for students (Walberg \& Haertel, 1990). According to Brown (2007, p.158), "no curriculum should be considered complete without some form of program evaluation". Therefore, not only to compete with the contemporary developments and demands in educational contexts but also to provide better educational experiences for all the stakeholders involved in any particular program, program evaluation processes should be made an important and natural component of the program as changing circumstances will automatically and naturally require these once the design, plan and implementation of a specific program have been performed (MacKay, 1998).

Beretta (1992) mentions the evolution of second language program evaluation as a distinct field of inquiry from the studies comparing the impact of teaching techniques (Keating, 1963; Scherer \& Wertheiner, 1964 \& Smith, 1970) and from those studies affected by Tyler's (1949) approach in comparing intended outcomes with actual outcomes (McIntyre \& Mitchell, 1983; Prabhu, 1987). Given the development of second language program evaluation in our local context, Turkey, it is seen that it is at its infancy in Turkey. In spite of the heightened interest on program evaluation and accreditation practices compared to the past worldwide, there is still a scarcity of program evaluation studies on foreign language education in Turkey with a few attempts in English language teaching programs. In this vein, Erozan (2005) conducted an evaluation case study of 10 language improvement courses at an undergraduate English language teacher education program through qualitative and quantitative methods. Similarly, Yel (2009) evaluated the English curricula for all of the grade levels in a Turkish high school by again using qualitative and quantitative data. Both studies reported the need for 
improvement especially in terms of the teaching of listening and speaking skills and some improvements with regard to student assessment. Another investigation into English program evaluation was conducted by Erdem (1999) who included more stakeholders compared to the two studies above into his qualitative and quantitative evaluation activities. In contrast to the need for classroom-related improvements revealed by the two studies above, the results from Erdem's (1999) study indicated a need for improvement with regard to more institutional practices such as the provision of in-service training activities for the teachers and continuous evaluation practices. Given the above studies, it appears that there is a need for program evaluation research related to tertiary foreign language education and this study will attempt to fill in this need.

\section{Purpose of the Study}

The purpose of this evaluation study was to determine the discrepancy between the current status of the MC and the desired status of it in relation to four focus areas as perceived by the teachers and students of the tertiary EFL program and to suggest areas of improvement in these areas. In other words, the study aimed at a) analyzing the MC by considering the different viewpoints with regard to four focus areas and b) identifying aspects that need to be improved. Thus, this evaluation study has sought to investigate the following research questions:

1. What is the current status of the course, MC in terms of its four fundamental aspects, aims and objectives, course content and materials, course conduct, student assessment and outcomes?

2. How do the instructors and the students taking the courses evaluate $\mathrm{MC}$ in terms of its four fundamental aspects, namely aims and objectives, course content and materials, course conduct, student assessment and outcomes?

3. What can be done to improve and strengthen the MC in terms of its four fundamental aspects, aims and objectives, course content and materials, course conduct, student assessment and outcomes? 
A Program Evaluation Study of the Main Course at a Preparatory Program:

A Case Study

\section{Curriculum Evaluation Model Used in the Study and Rationale for the Chosen Evaluation Model}

Based on the researcher's evaluation focus on improvement and formative evaluation, program type and the available conditions, Bellon and Handler (1982) Evaluation model was chosen as an appropriate evaluation model for this study. The evaluation model is credited with its three main elements and four focus areas. The three main elements of the model are status descriptions, the analysis activities and curriculum improvement components. The four focus areas refer to the components of a program, and they are goals, organization, operations and outcomes. The first focus area, goals, is related to the desired outcomes and expectations of the program. The second focal point, organization, deals with the organizational influences of the program. It includes such dimensions as available resources (human or physical resources) and organizational processes (decision making, planning processes etc.). The third area of focus, operations, refers to the stage where the curriculum implementation is examined, and where the translation of planned curriculum into the actual program could be observed. The fourth focal point for curriculum improvement, outcomes, refers to the evaluation of both intended and unintended program results.

In order to conduct the evaluation at the course level rather than the broader curriculum level for the purposes of this study, the four focus areas of the original model which are a) goals, b) organization, c) operations and d) outcomes have been replaced with the four main components of a typical course as in the follows respectively: a) aims and objectives, b) course content and materials, c) course conduct and d) student assessment and outcomes. On the modified evaluation model, RQ1 included status descriptions regarding the four dimensions, RQ2 included the analysis activities conducted in terms of these four components and RQ3 included curriculum improvement reported again in terms of these components. Figure 1 shows the adapted design of the study also with regard to the data collection tools and sources. 


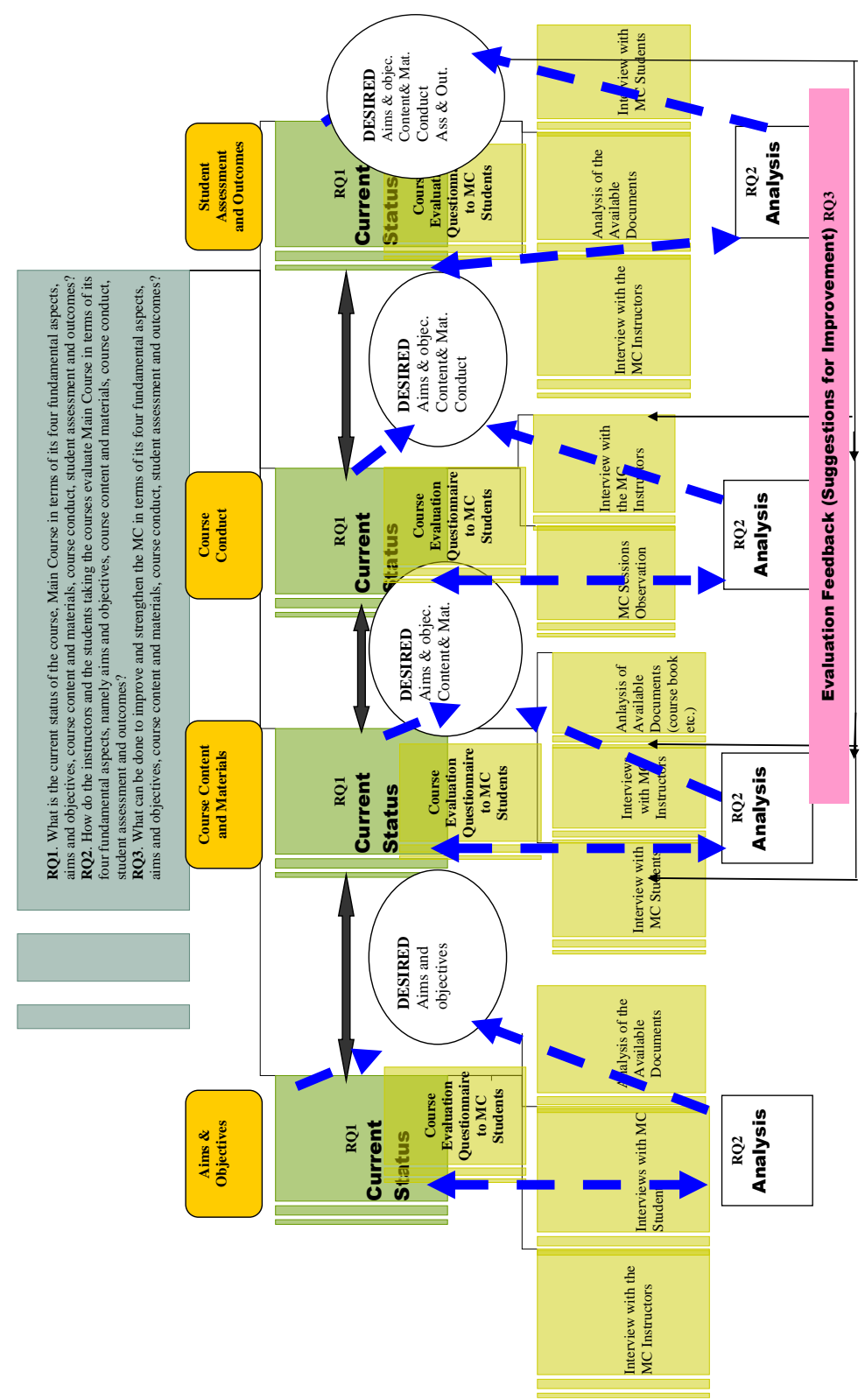

Figure 1. Design of the evaluation study (adapted from Bellon \& Handler, 1982, p. 11)

\section{Methodology}

This evaluation study has been designed as a case study that attempted to evaluate the MC offered at a preparatory program at a state university for the purposes of improvement through the use of quantitative and qualitative methods. In this regard, this evaluation study followed a mixed methods triangulation design as the aim was to "obtain different but complementary data on the same topic" (Morse, 1991, p. 122). 
A Program Evaluation Study of the Main Course at a Preparatory Program:

A Case Study

\section{Participants}

The subjects involved in this evaluation were MC learners and MC staff (instructors). Given the MC learners in more detail, the school had a total of 80 students according to the records at the department secretary. However, 5 of them dropped the course for several reasons. Therefore, when the study was conducted, the target population was 75 at the preparatory department, and there were a total of four classes at the preparatory department. 32 students from four different classes (16 males and 16 females) attended the questionnaire part, and hence the response rate has been calculated as 43 percent. For the interviews, six students recommended by their teachers as information-rich participants were contacted and volunteer students from those participated in the interviews. The ages of the students ranged between 18 and 20 .

Given the MC instructors, out of the six responsible from the preparatory program, three volunteered to take part in this study. These three female teachers taught the $\mathrm{MC}$ in both of the semesters. They were all non-native speakers of English. Their age range was between 28 and 35 , and they had teaching experience ranging between 5 to 13 years. As there is team teaching in the MC, first and second teacher taught in the same class, while the second teacher taught as a partner to another MC teacher (not attending the study) in another class, and the third instructor taught as a partner to two other classes. Hence, the teachers included in this study taught in all of the four MC classes of the program.

\section{Data Collection Instruments}

\section{Course evaluation questionnaire}

The course evaluation questionnaire was adapted from Erozan (2005), and the questionnaire aimed to elicit information on student perceptions with regard to the four fundamentals of a course, course aims and objectives, course content and materials, course conduct and student assessment procedures and also on their suggestions for the improvement of the MC. The questionnaire included five sections which were designed as student background and 
competency information, $\mathrm{MC}$ aims and objectives, $\mathrm{MC}$ content and materials, $\mathrm{MC}$ conduct and teaching-learning process and finally student assessment and performance. There were also open-ended items in the questionnaire to derive their suggestions as to the improvement of these components.

The course evaluation questionnaires were validated through taking expert opinions from two experts, one from an expert in the field of English language teaching and other from the field of educational sciences. Previous studies conducted by Erozan (2005) and Yel (2009) also reported the effectiveness of this questionnaire as a data collection tool.

\section{Interviews}

In order to gather further in-depth data about the students' perceptions and suggestions concerning the four dimensions of the course, interviews were performed with the students and the teachers. The questions of the interviews were parallel to those of the questionnaires in that as with the questionnaires, the researcher again aimed to gather data about the current status of the program, teachers' and students' opinions or evaluation of the procedures employed at each dimension of the course and their suggestions for the betterment of the course in each dimension. The interview schedules were adapted from Erozan (2005), and some questions were either deleted or combined with the others for the purposes of this present study.

\section{Observations}

Observations were performed in one of the preparatory classes of the department for 14 class hours. The aim of the observations was to gather information concerning mainly the teachinglearning process and course conduct. Using the observation form devised by Erozan (2005), the researcher took notes on the following: tasks, activities and methods used, student behavior, teacher behavior and the general atmosphere of the classroom.

\section{Documents}

As needed, examinations of available documents such as exam tools and sample exam papers, course books, other course materials and available documents concerning the rules and 
A Program Evaluation Study of the Main Course at a Preparatory Program:

A Case Study

structure of the preparatory program received from the administration and course instructors were performed in order to provide support for the above data collection tools.

\section{Data Analysis}

The data from the open-ended sections of the questionnaires were analyzed by means of listing the data under the four main evaluation dimensions it belonged to and then grouping the similar answers. The closed items in the questionnaires were analyzed by means of descriptive statistics. In order to analyze the results from the interviews, cross-case strategy in which the researcher grouped the answers, ideas and issues given by each participant into central themes was employed (Patton, 2002) following the transcription of the spoken data. Given the analyses for the MC session observations, the researcher used the key themes from the observation sheet or identified new codes/headings so as to arrive at holistic comments about the whole group.

\section{Findings}

\section{RQ1: What is the current status of the course, Main Course in terms of its four fundamental aspects, aims and objectives, course content and materials, course conduct, student assessment and outcomes?}

\section{Course Aims and Objectives}

The current aims and objectives of the program have been elicited with the help of the data obtained through teacher and student interviews and also from the analysis of the available documents concerning the general regulations in the program. In the teacher interviews, developing students' whole skills in English and developing students' proficiencies from elementary level to intermediate level of English were among the most recurring course goals. Parallel to what one of the instructors mentioned with the proficiency levels above, most of the students stated that this course aims to help students finish the preparatory year at the intermediate level of proficiency and it aims to develop all language skills. One instructor 
reported the objectives already given in their textbook as their course objectives and she stated as follows in a critical way:

"What the book offers as course aims is what we take as our MC aims, and this is not something true, we should determine our objectives depending on our context and learner characteristics, not on the book." (Teacher B)

There was no specific preparatory program goals and objectives document and the only document was the general rules and regulations document prepared when the program was first started in 2006. In order to gain more information about the course objectives and later use them in the course questionnaire to ask the perceptions of the students about the actualization of these course objectives, the researcher came together with the volunteer MC instructors to formulate a set of objectives for the MC. The researcher and course instructors worked on the objectives in the light of the textbook they used, and also by means of the teachers' opinions and suggestions on the final list. At the end, a list of objectives $(n=41)$ specified for speaking, listening, reading, writing, vocabulary and grammar was compiled (see Table $1 \&$ Table 3 in the section including findings for RQ2 below for sample objectives).

\section{Course Content and Materials}

According to the reports of all three MC teachers, course content encompasses language skills which are the four skills of language (reading, writing, listening and speaking) and also grammar and vocabulary knowledge. As they take the course book to specify their content, analyses of the course book also showed that listening tasks, conversation strategies, writing tasks, reading passages and grammar recognition exercises in the course book make up the content for the MC. Given the materials used for the MC, they have one main textbook. It has four subsequent strands, A, B, C and D. Other course materials include interactive white board format of the course book and a separate grammar textbook. There were also teacher-prepared videos for the students to watch and later to talk and write about.

\section{Course Conduct}

The teaching-learning process of the MC is explained in relation to the data elicited via observations and teacher interviews. According to the observations, the teachers usually 
A Program Evaluation Study of the Main Course at a Preparatory Program:

A Case Study

started the classes with making a connection with an earlier class or students' previous background knowledge. For the Modules A and B of the textbook, almost half of the observed class time in MC was spent on teacher lecturing the grammar topic, however, there is always question-answer pattern (interaction) between the teacher and the students especially as a warm-up to the grammar topic. There was always a pair or group work environment following the discussion of the grammar point or before the discussion of it as a type of lead-in for the students, and it seems that the teacher always tried to form a context to present the grammar topic to come. While working on the Modules C and D, students listened to an audio text and work on the follow-up questions and later they move to a speaking, reading or writing task. According to the interview results, MC instructors stated that the teaching-learning process in sometimes student-centered and sometimes teacher-centered. One of them asserted as in the following:

"I follow no specific methods in the classroom. I am into eclecticism, I believe in the power of using every approach when needed. I certainly disregard asking students directly perform speaking and writing. I think that giving language input within a task or within a daily activity would be more effective. In such context, students feel more relaxed. When I provide them with tasks, daily events or gamelike activities, they more strive to join in the activities and they get more motivated. At that point, I offer the key language points as the students are ready now, and this makes my lesson more quality." (Teacher A)

\section{Student Assessment and Course Outcomes}

On the basis of the data elicited from the teacher interviews and the available documents, MC has several assessment tools. Students' MC performance is calculated mainly based on two major assessment procedures: in-year grade $(50 \%)$ and final grade $(50 \%)$. When calculating the in-year grade, several assessments methods are included in it. These methods and their percentages are explained as follows: pop quizzes (10\%), common quizzes (20\%), three midterm exams $(60 \%)$ and class participation (10\%). Given the formats of exams in more detail, final exam exhibits the same format as the three midterms in that all is formed on the basis of 50 percent distribution for grammar and vocabulary and the remaining 50 is given to the all other language skills. Common quizzes are administered following the completion of 
the six units of the textbook, and they include two main components, a paper-based and an oral exam part.

RQ2: How do the instructors and the students taking the courses evaluate the current situation of the course, Main Course in terms of its four fundamental aspects, namely aims and objectives, course content and materials, course conduct, student assessment and outcomes?

\section{Course Aims and Objectives}

The course evaluation questionnaire related to this dimension show that the average score of the means of the respondents on the perceived fulfillment of the list of course objectives $(n=$ 41) was found to be 3.78 ( $S D=.64$ ) on a scale of 1 to 5 . The range of agreement (mean scores) was between 2.20 and 4.93 on the five-point Likert scale. This mean score on the realization of objectives part of the questionnaire implies that the respondents almost agree with the realization of the objectives listed in the questionnaire.

Table 1 below shows, with means and standard deviations, the ten most agreed objectives of the $\mathrm{MC}$ as reported by the questionnaire respondents. It is seen that half of the objectives that have been reported to be fulfilled belongs to the speaking skills among those ten in comparison to three reading and two listening objectives.

Table 1

The Ten Most Agreed Objectives of the MC

\begin{tabular}{llccc}
\hline $\begin{array}{l}\text { Objective } \\
\text { No }\end{array}$ & Objectives & $M$ & $S D$ & $\begin{array}{c}\text { Skill } \\
\text { Category }\end{array}$ \\
\hline 14 & $\begin{array}{l}\text { commenting/elaborating on the listened } \\
\text { material } \\
17\end{array}$ & 4.12 & .79 & Listening \\
18 & asking for clarification & 4.12 & .75 & Speaking \\
15 & asking questions & 4.09 & .89 & Speaking \\
\hline
\end{tabular}


A Program Evaluation Study of the Main Course at a Preparatory Program:

A Case Study

\begin{tabular}{llrrr}
\hline 21 & describe a photograph / picture & 4.03 & .98 & Speaking \\
2 & $\begin{array}{l}\text { identifying points of reference } \\
3\end{array}$ & 4.03 & 1.00 & Reading \\
22 & $\begin{array}{l}\text { guessing the meaning of unknown words (in a } \\
\text { given reading) } \\
\text { manage conversation more effectively by using } \\
\text { conversation strategies }\end{array}$ & 4.00 & .72 & Reading \\
$\begin{array}{l}\text { listening by note-taking } \\
43\end{array}$ & 3.97 & 1.09 & Speaking \\
& making inferences from a reading text & 3.97 & .91 & Reading \\
\hline
\end{tabular}

Table 2 displays the means of agreement for the respondents on the six language skills, which means that respondents appeared to confirm the realization of objectives regarding the listening skill over others, while the objectives for grammar were the least agreed one with regard to their realization (perceived fulfillment) by the questionnaire respondents.

Table 2

Mean Scores for the Objectives on the Language Skills

\begin{tabular}{lcc}
\hline Language Skill & $M$ & $S D$ \\
\hline Listening & 3.89 & .66 \\
Speaking & 3.86 & .74 \\
Reading & 3.77 & .57 \\
Vocabulary & 3.73 & .90 \\
Writing & 3.73 & .93 \\
Grammar & 3.64 & .78 \\
\hline
\end{tabular}

Table 3 below shows, with means and standard deviations, the ten least agreed objectives of the $\mathrm{MC}$ as reported by the questionnaire respondents. It is observed from the table that there is no listening objective that have been reported to be least fulfilled among the items, and that there are more objectives related to reading skills in comparison other skills. 
Table 3

The Ten Least Agreed Objectives of the MC

\begin{tabular}{|c|c|c|c|c|}
\hline $\begin{array}{l}\text { Objective } \\
\text { No }\end{array}$ & Objectives & $M$ & $S D$ & Skill Category \\
\hline 31 & $\begin{array}{l}\text { gain new grammar in natural contexts (conversation. } \\
\text { interviews and phone messages etc.) }\end{array}$ & 3.68 & 1.11 & Grammar \\
\hline 23 & communicate by using everyday language & 3.68 & 1.11 & Speaking \\
\hline 6 & identifying key ideas in a text & 3.66 & .83 & Reading \\
\hline 38 & $\begin{array}{l}\text { use new vocabulary in meaningful and personalized } \\
\text { interactions with classmates }\end{array}$ & 3.62 & 1.13 & Vocabulary \\
\hline 20 & give reasons & 3.62 & 1.18 & Speaking \\
\hline 30 & $\begin{array}{l}\text { engage in real-world writing tasks such as e-mail } \\
\text { messages. letters. short articles }\end{array}$ & 3.56 & 1.24 & Writing \\
\hline 5 & $\begin{array}{l}\text { deducing the underlying meaning in sentences or } \\
\text { parts of a text }\end{array}$ & 3.53 & .95 & Reading \\
\hline 40 & customize vocabulary learning & 3.5 & 1.21 & Vocabulary \\
\hline 7 & recognizing the relationship between ideas in a text & 3.48 & 1.03 & Reading \\
\hline 34 & $\begin{array}{l}\text { apply the appropriate grammar rules in their } \\
\text { language practices (as freer practices) }\end{array}$ & 3.41 & 1.10 & Grammar \\
\hline
\end{tabular}

Given the means on a five-point Likert scale on the entire objectives part of the questionnaire and also the categorization of these objectives in skills, it has been revealed that respondents' degree of confirmation for the realization of the great majority objectives fell within somewhere that could be categorized as closer to the point of agreement on the entire objectives part of the questionnaire, as well as on the skills categories. Given the question of which type of language skills respondents showed confirmation over others, it is seen that the students appear to more agree on the realization of listening objectives followed marginally by the speaking objectives.

In addressing whether the course met students' expectations, almost 69 (Strongly Agree and Agree) percent of the respondents reported to the question "MC met my expectations" positively $(M=3.77, S D=1.12)$. Given the question " MC met my needs", 61.5 (Strongly Agree and Agree aggregated) percent of the students reported that the MC answered to their needs with regard to listening, almost 69 percent with regard to speaking, almost 73 percent 
A Program Evaluation Study of the Main Course at a Preparatory Program:

\section{A Case Study}

with regard to writing, and 71 percent with regard to reading skills. The Table 4 below presents the above results.

Table 4

Expectations and Needs Met by the MC

\begin{tabular}{lccccccc}
\hline \multicolumn{1}{c}{ Questions } & SA & A & NS & D & SD & $M$ & $S D$ \\
\hline MC met my expectations & $8(25.8)$ & $14(45.2)$ & $5(16.1)$ & $2(6.5)$ & $2(6.5)$ & 3.77 & 1.12 \\
$\begin{array}{l}\text { MC met my needs in terms of } \\
\text { listening skills }\end{array}$ & $3(11.5)$ & $13(50)$ & $5(19.2)$ & $3(11.5)$ & $2(7.7)$ & 3,46 & 1.10 \\
$\begin{array}{l}\text { MC met my needs in terms of } \\
\text { speaking skills }\end{array}$ & $4(15.4)$ & $14(53.8)$ & $3(11.5)$ & $4(15.4)$ & $1(3.8)$ & 3.61 & 1.06 \\
$\begin{array}{l}\text { MC met my needs in terms of } \\
\text { writing skills }\end{array}$ & $4(12.9)$ & $19(61.3)$ & $3(9.7)$ & $3(9.7)$ & $2(6.5)$ & 3.64 & 1.05 \\
$\begin{array}{l}\text { MC met my needs in terms of } \\
\text { reading skills }\end{array}$ & $7(22.6)$ & $15(48.4)$ & $7(22.6)$ & $1(3.2)$ & $1(3.2)$ & 3.84 & .93 \\
& & & & & & &
\end{tabular}

*Note. SA: Strongly agree / A: Agree / NS: Not sure / D: Disagree / SD: Strongly disagree.

*Note. $f(\%)$

In the interviews conducted with the students taking MC, all of the students stated that the course met their expectations and needs to a great extent. One of them further explained that the course helped him to be more knowledgeable in grammar as something he expected when coming to the preparatory school. One of them explained as follows:

"When I first decided to come to the preparatory school, I had very big expectations. If I say my expectations have not been met, it would be impossible to say like this, but I can say that my expectations were met up to 80 percent in talking about percentages. For example, what has not been met? I would expect different level classes at the prep school". (Student A)

On the other hand, the second student stated he had expected his listening skills to improve more, but he can't say that his listening did improve as the other skills did. He argued:

"Our listening skills could have been better. My writing is OK in that I can express myself by writing. My speaking is so so, I can speak English. Our instruction for speaking development was good, we learn a lot of everyday language to use. However, in listening I always feel this difficulty when listening to videos, songs, texts and radio, for instance”. (Student C) 
Paralleling to what the students said with respect to the achievement of objectives, one of the MC instructors said that she believed that they achieved most of the objectives. She further explained as in the follows:

"I believe that we achieved most of we aim with this course. However, there are some variations among students in relation to the fulfillment of the objectives. These variations are observed in students themselves in relation to different language skills and also among students. There could be a huge variation in one student's listening and writing development for example. Or while some students in one class could graduate at the intermediate level, there were those who were still at the elementary level. Therefore, the objectives have been achieved to most extent, but there are these variations". (Teacher A)

\section{Course Content and Materials}

It has been seen that in general, students taking MC have somewhat positive attitudes toward most of the issues in MC concerning course content and materials given the means of items on the questionnaire. Table 5 demonstrates the opinions of the respondents on several issues relevant to course content and materials.

Table 5

Students' Opinions about MC Content and Materials

\begin{tabular}{|c|c|c|c|c|c|c|c|}
\hline Items & $\widetilde{\omega}$ & $\varangle$ & $\sum$ & $\theta$ & ลิ & & \\
\hline & & & $f$ & & & $M$ & $S D$ \\
\hline $\begin{array}{l}\text { 1. The course materials provided me with what I needed to } \\
\text { know or do. }\end{array}$ & 7 & 16 & 5 & 3 & 1 & 3.78 & 1.01 \\
\hline 2. The course materials were appropriate to my interests. & 5 & 15 & 8 & 4 & - & 3.66 & .90 \\
\hline $\begin{array}{l}\text { 3. The course materials fit my long term goals in terms of } \\
\text { listening skills. }\end{array}$ & 4 & 15 & 10 & 3 & - & 3.62 & .83 \\
\hline $\begin{array}{l}\text { 4. The course materials fit my long term goals in terms of } \\
\text { speaking skills }\end{array}$ & 4 & 13 & 8 & 7 & - & 3.44 & .98 \\
\hline $\begin{array}{l}5 \text {. The course materials fit my long term goals in terms of } \\
\text { reading skills. }\end{array}$ & 4 & 12 & 14 & 2 & - & 3.56 & .80 \\
\hline $\begin{array}{l}\text { 6. The course materials fit my long term goals in terms of } \\
\text { writing skills. }\end{array}$ & 7 & 11 & 10 & 2 & 2 & 3.59 & 1.10 \\
\hline 7. The topics and themes in the materials were interesting. & 10 & 11 & 8 & 3 & - & 3.87 & .97 \\
\hline
\end{tabular}


Items

8. The course materials offered continuity (between earlier
and later parts).

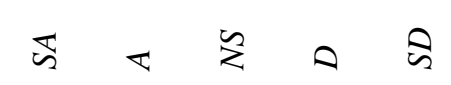

9. The listening skills taught in MC were useful for improving my general listening ability in English.

10. The speaking skills taught in MC were useful for improving my general speaking ability in English.

11. The reading skills taught in MC were useful for improving my general reading ability in English.

12. The writing skills taught in MC were useful for improving my general writing ability in English.

13. The topics were presented sequentially, i.e. building upon prior learning.

14.MC course pack was appropriately priced.

15. The materials were in line with the course objectives.

16. Course materials were sufficient to improve my listening skills.

17. Course materials were sufficient to improve my speaking skills.

18. Course materials were sufficient to improve my reading skills.

19. Course materials were sufficient to improve my writing skills.

20. It was easy to use the course materials.

21. Exercises/tasks in the ELT 121 course pack were effective in improving my listening skills.

22. Exercises/tasks in the ELT 121 course pack were effective in improving my speaking skills.

23. Exercises/tasks in the ELT 121 course pack were effective in improving my reading skills.

24. Exercises/tasks in the ELT 121 course pack were effective in improving my writing skills.

25 . The course materials had variety.

26. I had difficulty in following the course materials.

27. The course materials helped me to improve my listening skills.

28. The course materials helped me to improve my speaking skills.

29. The course materials helped me to improve my reading skills.

\begin{tabular}{|c|c|c|c|c|c|c|}
\hline 11 & 11 & 6 & 3 & 1 & 3.87 & 1.10 \\
\hline 4 & 17 & 4 & 6 & 1 & 3.53 & 1.05 \\
\hline 2 & 15 & 10 & 3 & 1 & 3.45 & .89 \\
\hline 5 & 18 & 7 & 1 & 1 & 3.78 & .87 \\
\hline 6 & 15 & 6 & 1 & 4 & 3.56 & 1.22 \\
\hline 9 & 12 & 6 & 5 & - & 3.78 & 1.04 \\
\hline 2 & 4 & 2 & 4 & 19 & 1.90 & 1.35 \\
\hline 4 & 19 & 6 & 2 & 1 & 3.72 & .89 \\
\hline 6 & 12 & 7 & 5 & 2 & 3.47 & 1.16 \\
\hline 3 & 12 & 13 & 2 & 2 & 3.37 & .07 \\
\hline 6 & 10 & 12 & 1 & 1 & 3.63 & .96 \\
\hline 7 & 9 & 9 & 3 & 2 & 3.53 & 1.17 \\
\hline 7 & 14 & 7 & 3 & 1 & 3.72 & 1.02 \\
\hline 4 & 16 & 7 & 5 & - & 3.59 & .91 \\
\hline 5 & 16 & 6 & 4 & 1 & 3.62 & 1.01 \\
\hline 3 & 20 & 6 & 1 & 2 & 3.66 & .94 \\
\hline 8 & 14 & 8 & 1 & 1 & 3.84 & .95 \\
\hline 4 & 12 & 11 & 4 & 1 & 3.44 & .98 \\
\hline 2 & 7 & 10 & 8 & 5 & 2.78 & 1.16 \\
\hline 5 & 13 & 10 & 4 & - & 3.59 & .91 \\
\hline 7 & 12 & 9 & 2 & 1 & 3.71 & 1.01 \\
\hline 6 & 17 & 7 & 2 & - & 3.84 & .81 \\
\hline
\end{tabular}


Items

\begin{tabular}{|c|c|c|c|c|c|c|c|}
\hline \multirow{3}{*}{$\begin{array}{l}\text { 30. The course materials helped me to improve my writing } \\
\text { skills }\end{array}$} & $\widetilde{\omega}$ & $\varangle$ & $z$ & O & 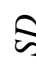 & \multirow{3}{*}{$\begin{array}{l}M \\
3.84\end{array}$} & \multirow{3}{*}{$\begin{array}{l}S D \\
.77\end{array}$} \\
\hline & \multicolumn{5}{|c|}{$f$} & & \\
\hline & 6 & 16 & 9 & 1 & - & & \\
\hline 31. The course materials were visually attractive. & 10 & 12 & 6 & 3 & 1 & 3.84 & 1.08 \\
\hline $\begin{array}{l}\text { 32. The materials were appropriate to our proficiency level in } \\
\text { English. }\end{array}$ & 4 & 16 & 7 & 3 & 1 & 3.61 & .95 \\
\hline $\begin{array}{l}\text { 33. There was a need for supplementary materials to improve } \\
\text { my listening skills. (i.e. supplementary materials should have } \\
\text { been used) }\end{array}$ & 5 & 15 & 5 & 3 & 4 & 3.44 & 1.24 \\
\hline $\begin{array}{l}\text { 34. There was a need for supplementary materials to improve } \\
\text { my speaking skills. (i.e. supplementary materials should have } \\
\text { been used) }\end{array}$ & 6 & 14 & 7 & 3 & 2 & 3.59 & 1.10 \\
\hline $\begin{array}{l}\text { 35. There was a need for supplementary materials to improve } \\
\text { my reading skills. (i.e. supplementary materials should have } \\
\text { been used) }\end{array}$ & 4 & 14 & 6 & 3 & 4 & 3.35 & 1.23 \\
\hline $\begin{array}{l}\text { 36. There was a need for supplementary materials to improve } \\
\text { my writing skills. (i.e. supplementary materials should have } \\
\text { been used) }\end{array}$ & 6 & 16 & 4 & 2 & 4 & 3.56 & 1.24 \\
\hline
\end{tabular}

While the respondents found the course materials and course content useful for improving their reading ability (Items $11(M=3.78, S D=.87), 18(M=3.63, S D=.96), 23(M=3.66, S D=.94)$ and $29(M=3.84, S D=.81)$, and they found them less useful respectively for writing ability (Items $12(M=3.56, S D=1.22), 19(M=3.53, S D=1.17), 24(M=3.84, S D=.95)$ and $30(M$ $=3.84, S D=.77)$ ), listening ability (Items $9(M=3.53, S D=1.05), 16(M=3.47, S D=1.16)$, $21(M=3.59, S D=.91)$ and $27(M=3.59, S D=.91))$ and speaking ability (Item $10(M=3.45$, $S D=.89), 17(M=3.37, S D=.07), 22(M=3.62, S D=1.01)$ and $28(M=3.71, S D=1.01))$.

In contrast, in the teacher interviews, all the teachers expressed their dissatisfaction with the course materials' usefulness for the development of reading skills. The teachers were expecting the book to offer and teach more strategies for better reading comprehension. For the other skills, two of the interviewed teachers asserted that they were happy with what the materials offered, but one teacher who is mostly teaching Modules A and B pointed out a need for the book to provide more and varied contexts for grammar use so that the students could see the grammar they learn in different contexts, and she says "the more the depth of processing is, the more they learn". 
A Program Evaluation Study of the Main Course at a Preparatory Program:

A Case Study

Moreover, students positively evaluated (almost agreed with) such issues regarding course content materials as interesting topics and themes $(M=3.87, S D=1.10)$, parallelism between course objectives and materials (Item $3(M=3.62, S D=.83)$ for listening, Item $5(M=3.56$, $S D=.80$ for reading, Item $6(M=3.59, S D=1.10$ for writing and item $4(M=3.44, S D=.98)$ for speaking), continuity between the parts of the course materials $(M=3.87, S D=1.10)$, easiness to use the course materials $(M=3.72, S D=1.02)$, visual attractiveness of the course materials $(M=3.84, S D=1.08)$ and appropriacy of the course materials to students proficiency levels $(M=3.61, S D=.95)$. There was only one item (Item 14) which stood different from the others in that students showed almost no agreement $(M=1.90, S D=1.35)$, and thus it seems that students have some problems about the cost of the books. In line with the above evaluations of the students, the MC instructors agreed with the interesting topics, continuity among the modules, visual attractiveness and easiness to use the materials.

Given the course materials, as shown above in Table 6, the students believed in the usefulness of materials used in the MC with textbook being the most favored course material among others (aggregated $87 \%$ for Strongly Agree and Agree), the grammar book being the least favored one (aggregated $48 \%$ for Strongly Agree and Agree). It is also evident that respondents also liked the handouts teachers prepared and the workbook accompanied to the course book.

Table 6

Students' Opinions about the Usefulness of MC Materials

\begin{tabular}{lccccccc}
\hline \multicolumn{1}{c}{ Questions } & \multicolumn{1}{c}{ SA } & A & NS & D & SD & $M$ & $S D$ \\
\hline Coursebook & $15(48.4)$ & $12(38.7)$ & $1(3.2)$ & $1(3.2)$ & $2(6.5)$ & 4.19 & 1.11 \\
Workbook & $12(40)$ & $10(33.3)$ & $5(16.7)$ & $2(6.7)$ & $1(3.3)$ & 4.00 & 1.08 \\
Grammar Book & $6(19.4)$ & $9(29)$ & $5(16.1)$ & $7(22.6)$ & $4(12.9)$ & 3.19 & 1.35 \\
Online Textbook Tool & $6(20)$ & $12(40)$ & $4(13.3)$ & $4(13.3)$ & $4(13.3)$ & 3.40 & 1.33 \\
$\begin{array}{l}\text { Handouts prepared by the } \\
\text { teachers }\end{array}$ & $17(53.1)$ & $9(28.1)$ & $3(9.4)$ & $1(3.1)$ & $2(6.3)$ & 4.19 & 1.15 \\
$\begin{array}{l}\text { Reading exercises assigned } \\
\text { Ekstra videos }\end{array}$ & $6(18.8)$ & $12(37.5)$ & $7(21.9)$ & $3(9.4)$ & $4(12.5)$ & 3.41 & 1.27 \\
\hline
\end{tabular}

*Note. SA: Strongly agree / A: Agree / NS: Not sure / D: Disagree / SD: Strongly disagree; $f(\%)$ 
In relation to the specific course materials used, all of the interviewed students expressed their dislike with the grammar book during the interviews, which is also put forth by two of the teachers interviewed. The students were mostly positive about the topics and themes covered in the textbook. Likewise, all of the teachers reported that they were satisfied with the course materials and content covered. One teacher said:

"This course book is a very daily course book. I think there was nothing that would not interest the students. Students were encouraged to work with daily language and some other formal content. Therefore, the book included these two poles, formal and informal content. I heard some students asking why we deal with job interviews for example. I do not think that this topic is not an interest to the students. However, because of the students' current situation, they do not expect to talk about this topic, but they will have to expect it for their future, and they are not aware of it for now. I mean this job interview may work for their future use, but now they do not care about it." (Teacher C)

Most of the interviewed students reported their satisfaction with the teacher prepared handouts especially for learning the phrases and expressions in English. For the use of the accompanying online tool, all the teachers were in agreement that the technological tools offered by the course book were not used efficiently by the students. One of the teachers mentioned as follows:

"There are lots of technological tools offered for the students to use for self-study purposes. For some reasons, either because of technological constraints, or their own reasons, they do not use these tools. We should find a way for it because students need these creative and rich practices." (Teacher $\mathrm{B})$

\section{Course Conduct}

The results of the course evaluation questionnaire (Table 7) show that the range of agreement (mean scores) was between 2.19 and 5.00 on the five-point Likert scale. This mean score implies that the students evaluated the teaching-learning process in the positive direction.

The results also reveal that (see Table 7) the students considered the teachers' use of audiovisual aids $(M=4.28, S D=.81)$, teacher encouragement for student participation $(M=4.26$, $S D=.68)$, teachers' use of board $(M=4.12, S D=.83)$, good student-teacher interaction $(M=$ $4.12, S D=.97)$, teacher help $(M=4.06, S D=.98)$, efficient class time use $(M=4.06, S D=$ .99 ) as the most effective aspects of the teaching-learning process. Conversely, individual work 
A Program Evaluation Study of the Main Course at a Preparatory Program:

A Case Study

$(M=2.78, S D=1.29)$, and use of only English in class $(M=3.00, S D=1.16)$, were considered to be the least effective aspects.

Table 7

Students' Opinions about the Teaching-Learning Process

\begin{tabular}{|c|c|c|c|c|c|c|c|}
\hline Items & $\widetilde{s}$ & $\varangle$ & $\sum$ & ○ & 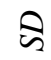 & & \\
\hline & \multicolumn{5}{|c|}{$f$} & $M$ & $S D$ \\
\hline 1. There was an efficient use of time in class. & 5 & 9 & 1 & & 1 & 4.06 & .99 \\
\hline $\begin{array}{l}\text { 2. There was a good student-teacher interaction in the } \\
\text { course. }\end{array}$ & 14 & 11 & 4 & 3 & - & 4.12 & .97 \\
\hline $\begin{array}{l}\text { 3. The students had cooperative relationships with each } \\
\text { other. }\end{array}$ & 12 & 14 & 3 & 1 & 2 & 4.03 & 1.09 \\
\hline 4. A variety of activities was used in the course. & 8 & 13 & 6 & 4 & 1 & 3.72 & 1.08 \\
\hline 5. The teacher was teaching in an interesting way. & 10 & 9 & 9 & 4 & - & 3.78 & 1.04 \\
\hline 6. It was easy to follow the teacher. & 7 & 17 & 5 & 2 & 1 & 3.84 & .95 \\
\hline 7. The teacher's instructions were clear. & 10 & 12 & 8 & 1 & 1 & 3.91 & .99 \\
\hline $\begin{array}{l}\text { 8. The teaching methodology of the teacher was } \\
\text { effective in our learning. }\end{array}$ & 9 & 15 & 6 & 1 & 1 & 3.94 & .95 \\
\hline $\begin{array}{l}\text { 9. The teacher was encouraging us to participate in the } \\
\text { lessons. }\end{array}$ & 12 & 15 & 4 & - & - & 4.26 & .68 \\
\hline $\begin{array}{l}\text { 10.The teacher used audio-visual aids (OHP, video, } \\
\text { tape-recorder, etc.) effectively in the lessons. }\end{array}$ & 15 & 12 & 4 & 1 & - & 4.28 & .81 \\
\hline 11.The teacher was using the board effectively. & 11 & 16 & 3 & 2 & - & 4.12 & .83 \\
\hline $\begin{array}{l}\text { 12.The teacher was giving equal attention to all } \\
\text { students in the class. }\end{array}$ & 8 & 14 & 4 & 5 & 1 & 3.72 & 1.11 \\
\hline $\begin{array}{l}\text { 13. The teacher corrected our mistakes in an effective } \\
\text { way. }\end{array}$ & 9 & 16 & 3 & 3 & 1 & 3.91 & 1.03 \\
\hline 14. I preferred to work individually in class. & 3 & 7 & 9 & 6 & 7 & 2.78 & 1.29 \\
\hline 15. I preferred to work with (a) partner(s) in class. & 8 & 16 & 6 & 1 & 1 & 3.91 & .93 \\
\hline 16. I used only English in class. & 3 & 8 & 11 & 6 & 4 & 3.00 & 1.16 \\
\hline 17. The lessons were taught in an interesting way. & 5 & 16 & 8 & 2 & 1 & 3.69 & .93 \\
\hline 18. Other students helped me to learn in this course. & 5 & 19 & 4 & 1 & 3 & 3.69 & 1.09 \\
\hline 19.The teacher helped me to learn in this course. & 10 & 18 & 2 & - & 2 & 4.06 & .98 \\
\hline $\begin{array}{l}20 \text {. The teacher was giving sufficient feedback on our } \\
\text { performance. }\end{array}$ & 7 & 16 & 7 & - & 2 & 3.81 & .99 \\
\hline $\begin{array}{l}\text { 21. The students were giving sufficient feedback on } \\
\text { each other's performance. }\end{array}$ & 5 & 17 & 8 & - & 2 & 3.72 & .96 \\
\hline
\end{tabular}

* SA: Strongly agree / A: Agree / NS: Not sure / D: Disagree / SD: Strongly disagree 
In line with the questionnaire results on the learning-teaching process, in the interviews, most students emphasized the good and friendly teacher behavior as the most important characteristics of the English class. Accordingly, students had positive attitudes about the teacher roles and student-teacher interaction. As is also understood with the results of the observations, there was a good classroom interaction. No student disciplinary problems arose during the observed class time. The observation results also showed that the students were accustomed to work in cooperation, in peers and groups. When the teacher arranged the groups or provided the instruction, students tended to directly start working in their peers or groups. One thing realized during the observation was the frequent use of students' native language (i.e. Turkish) among the students, and there were also frequent instances that they asked most of their questions in Turkish to the MC teachers.

Given the frequency of methods employed in the $\mathrm{MC}$, as depicted in Table 8, teacher questioning $(M=3.39, S D=.67)$, teacher lecture $(M=3.35, S D=.61)$, assignments $(M=3.31$, $S D=.78)$, teacher's correcting mistakes $(M=3.28, S D=.58)$ and computer-aided activities $(M=3.19, S D=.69)$ were included as the most frequent activities, while songs $(M=2.25,=$ $1.05)$, games $(M=2.40, S D=.93)$, student peer evaluation $(M=2.53, S D=.94)$, role-plays $(M$ $=2.57, S D=1.10)$ and projects $(M=2.59, S D=.98)$ were considered the five least frequent methods employed in the MC as perceived by the students. Given the least used activities and methods, it would be meaningful to contend that those methods of discussion, projects, roleplays, student peer evaluation, games and songs show mean values relatively lower than the rest (all below point 2.00) with regard to sufficiency of use. Given the average means for the methods used, only two of the methods (games and songs) have been observed to have means close to 2 (not sufficient) on a 4- (more than I want) point scale, which would mean that these two methods have been used marginally in these classes and point out to a need to practice them more. It is also seen that most methods (excluding the two above) have been employed at the level of sufficiency (i.e. means above 2.00). 
A Program Evaluation Study of the Main Course at a Preparatory Program:

\section{A Case Study}

Table 8

Activities and Methods Used in the MC

\begin{tabular}{|c|c|c|c|c|c|c|}
\hline & $\begin{array}{l}\text { More than I } \\
\text { wanted }\end{array}$ & $\begin{array}{l}\text { The } \\
\text { right amount }\end{array}$ & $\begin{array}{l}\text { Not } \\
\text { sufficient }\end{array}$ & None & $M$ & $S D$ \\
\hline Teacher questioning & $14(45.2)$ & $16(51.6)$ & $1(3.2)$ & - & 3.39 & .67 \\
\hline Teacher lecture & $13(41.9)$ & $16(51.6)$ & $2(6.5)$ & - & 3.35 & .61 \\
\hline Assignment/Homework & $15(46.9)$ & $13(40.6)$ & $3(9.4)$ & $1(3.1)$ & 3.31 & .78 \\
\hline $\begin{array}{l}\text { Teacher correction of } \\
\text { mistakes }\end{array}$ & $11(34.4)$ & $19(59.4)$ & $2(6.3)$ & - & 3.28 & .58 \\
\hline Computer-aided activities & $11(34.4)$ & $16(50.00)$ & $5(15.6)$ & - & 3.19 & .69 \\
\hline Pair work & $11(34.4)$ & $15(46.9)$ & $6(18.8)$ & - & 3.16 & .72 \\
\hline Group work & $9(28.1)$ & $18(56.3)$ & $4812.4)$ & $1(3.1)$ & 3.09 & .73 \\
\hline $\begin{array}{l}\text { Reading aloud by } \\
\text { students }\end{array}$ & $7(21.9)$ & $20(62.5)$ & $4(12.5)$ & $1(3.1)$ & 3.03 & .69 \\
\hline Tape/CD listening & $11(34.4)$ & $13(40.6)$ & $5(15.6)$ & $3(9.4)$ & 3.00 & .95 \\
\hline $\begin{array}{l}\text { Reading aloud by } \\
\text { teachers }\end{array}$ & $6(18.8)$ & $20(62.5)$ & $4(12.5)$ & $2(6.3)$ & 2.94 & .75 \\
\hline Video sessions & $8(25.00)$ & $13(40.6)$ & $10(31.3)$ & $1(3.1)$ & 2.87 & .83 \\
\hline Student self-correction & $4(12.5)$ & $19(59.4)$ & $6(18.8)$ & $3(9.4)$ & 2.75 & .80 \\
\hline Student presentations & $10(31.3)$ & $9(28.1)$ & $8(25.00)$ & $5(15.6)$ & 2.75 & 1.08 \\
\hline Student self-evaluation & $3(9.4)$ & $18(56.3)$ & $10(31.3)$ & $1(3.1)$ & 2.72 & .68 \\
\hline Student peer-correction & $3(9.4)$ & $18(56.3)$ & $10(31.3)$ & $1(3.1)$ & 2.72 & .68 \\
\hline Translation & $5(16.1)$ & $15(48.4)$ & $8(25.8)$ & $3(9.7)$ & 2.71 & .86 \\
\hline Individual silent study & $2(6.3)$ & $21(65.6)$ & $6(18.8)$ & $3(9.4)$ & 2.69 & .74 \\
\hline Discussion & $3(9.4)$ & $16(50.00)$ & $10(31.3)$ & $3(9.4)$ & 2.59 & .78 \\
\hline Projects & $6(18.8)$ & $12(37.5)$ & $9(28.1)$ & $5(15.6)$ & 2.59 & .98 \\
\hline Role-plays & $7(23.3)$ & $10(33.3)$ & $6(20.00)$ & $7(23.3)$ & 2.57 & 1.10 \\
\hline Student peer evaluation & $5(15.6)$ & $12(37.5)$ & $10(31.3)$ & $5(15.6)$ & 2.53 & .95 \\
\hline Games & $4(13.3)$ & $9(30.00)$ & $\begin{array}{c}12 \\
(40.00)\end{array}$ & $5(16.7)$ & 2.40 & .93 \\
\hline Songs & $4(12.5)$ & $10(31.3)$ & $8(25.0)$ & $4(31.3)$ & 2.25 & 1.05 \\
\hline
\end{tabular}

Note. SA: Strongly agree / A: Agree / NS: Not sure / D: Disagree / SD: Strongly disagree Note. $f(\%)$

In the interviews, half of the students said that all the activities and tasks were interesting and useful. On the other hand, the remaining students said the activities were good, but more could have been done by using variety of activities and tasks such as discussions, role-plays, 
presentation activities and use of videos and films. For instance, one student pointed out the need for presentation activities as in the following:

"Due to the professions we will have in the future, we will be communicating with people, and presentation will be a part of this communication at the work place. Moreover, while preparing your presentation you are learning new things and developing your research skills as well." (Student E)

When talking about the teaching-learning process with the teachers, working with partner teachers arouse as a problem area. One teacher reported as follows:

"Though we need to follow the same book and same procedures in the MC, the teaching-learning process of the MC classrooms are too different from one another. I know they cannot be the same to 100 percent, but they should have a lot in common. Those teaching the MC are not in good contact with one another unless they have a good relationship in their social life. I think if we come together to discuss our teaching, we will all benefit from it. There should be more interaction between the colleagues." (Teacher $\mathrm{C}$ )

Parallel to what the above teacher suggests, another MC instructor complains about the difficulty to work with a partner as in the following:

"If you have a partner that you could get on well, it is good. However, my partner is not very willing to work together. What I mean is that she sees her lesson as a separate lesson from mine, and when I ask her whether she did an activity for the students, for example, she says, "this is your duty, I cannot do that". I think we should work together for this course. We should come together and discuss the things." (Teacher A)

\section{Student Assessment and Outcomes}

The results of the student questionnaire showed that the majority of the students possessed positive opinions about the assessment procedures of MC as represented in Table 9. 
A Program Evaluation Study of the Main Course at a Preparatory Program:

A Case Study

Table 9

Students' Opinions about the Assessment Procedures of the MC

\begin{tabular}{|c|c|c|c|c|c|c|c|}
\hline \multirow[b]{3}{*}{$\begin{array}{l}\text { 1. We were assessed on the things we practiced } \\
\text { in the lessons. }\end{array}$} & $\overleftarrow{5}$ & $\varangle$ & $\Sigma$ & $\theta$ & ڤิ & \multirow[b]{2}{*}{$M$} & \multirow[b]{2}{*}{$S D$} \\
\hline & \multicolumn{5}{|c|}{$f$} & & \\
\hline & 16 & 7 & - & 2 & - & 4.48 & .87 \\
\hline 2. The directions on the tests were clear. & 11 & 12 & 5 & 3 & - & 4.00 & .97 \\
\hline $\begin{array}{l}\text { 3. We were informed about the evaluation } \\
\text { criteria before our exams. }\end{array}$ & 7 & 17 & 4 & 3 & & 3.90 & .87 \\
\hline 4. The test questions were difficult. & 4 & 12 & 10 & 5 & - & 3.48 & .93 \\
\hline $\begin{array}{l}\text { 5. The test results demonstrate my actual } \\
\text { proficiency / ability in English. }\end{array}$ & 3 & 12 & 7 & 9 & - & 3.29 & 1.01 \\
\hline $\begin{array}{l}\text { 6. The test results demonstrate my actual } \\
\text { proficiency / ability in speaking skills }\end{array}$ & 4 & 12 & 9 & 6 & - & 3.45 & .96 \\
\hline $\begin{array}{l}\text { 7. The test results demonstrate my actual } \\
\text { proficiency / ability in reading skills. }\end{array}$ & 3 & 17 & 2 & 8 & 1 & 3.42 & 1.09 \\
\hline $\begin{array}{l}\text { 8. The test results demonstrate my actual } \\
\text { proficiency / ability in listening skills }\end{array}$ & 2 & 16 & 7 & 3 & 2 & 3.43 & 1.01 \\
\hline $\begin{array}{l}\text { 9. The test results demonstrate my actual } \\
\text { proficiency / ability in writing skills }\end{array}$ & 2 & 14 & 8 & 5 & 2 & 3.29 & 1.04 \\
\hline $\begin{array}{l}\text { 10. My listening skills have been correctly } \\
\text { measured in the course. }\end{array}$ & 4 & 16 & 6 & 4 & 1 & 3.58 & .99 \\
\hline $\begin{array}{l}\text { 11. My speaking skills have been correctly } \\
\text { measured in the course. }\end{array}$ & 5 & 11 & 10 & 4 & 1 & 3.48 & 1.03 \\
\hline $\begin{array}{l}\text { 12. My writing skills have been correctly } \\
\text { measured in the course. }\end{array}$ & 3 & 19 & 6 & 2 & - & 3.77 & .73 \\
\hline $\begin{array}{l}\text { 13. My reading skills have been correctly } \\
\text { measured in the course. }\end{array}$ & 4 & 14 & 7 & 4 & - & 3.62 & .90 \\
\hline 14. The grading was fair. & 7 & 11 & 8 & 4 & 1 & 3.61 & 1.08 \\
\hline $\begin{array}{l}\text { 15. HW/assignments were relevant to the } \\
\text { course aims. }\end{array}$ & 9 & 15 & 6 & 1 & - & 4.03 & .79 \\
\hline 16. My performance in this course was good. & 6 & 15 & 6 & 3 & - & 3.80 & .89 \\
\hline $\begin{array}{l}\text { 17. My listening skills have improved after this } \\
\text { course. }\end{array}$ & 4 & 18 & 5 & 4 & - & 3.71 & .86 \\
\hline $\begin{array}{l}\text { 18. My speaking skills have improved after } \\
\text { this course. }\end{array}$ & 6 & 19 & 5 & 1 & - & 3.97 & .71 \\
\hline $\begin{array}{l}\text { 19. My reading skills have improved after this } \\
\text { course. }\end{array}$ & 6 & 19 & 5 & 1 & & 3.97 & .71 \\
\hline $\begin{array}{l}\text { 20. My writing skills have improved after this } \\
\text { course. }\end{array}$ & 7 & 18 & 5 & 1 & & 4.00 & .73 \\
\hline
\end{tabular}


21. I received sufficient feedback on my performance in the lesson.

22. I received sufficient feedback on my performance in the tests.

\begin{tabular}{|c|c|c|c|c|c|c|}
\hline$\widetilde{s}$ & $\varangle$ & $\bar{z}$ & $\theta$ & ڤs & & \\
\hline \multicolumn{5}{|c|}{$f$} & $M$ & $S D$ \\
\hline 3 & 19 & 5 & 3 & 1 & 3.64 & .91 \\
\hline 3 & 15 & 7 & 3 & 1 & 3.55 & .95 \\
\hline
\end{tabular}

Note. SA: Strongly agree / A: Agree / NS: Not sure / D: Disagree / SD: Strongly disagree

The results reveal that the students expressed agreement with the issues concerning being assessed on the things they have practiced in the lessons $(M=4.48, S D=87)$, relevancy of assignments to the course aims $(M=4.03, S D=.79)$ and the clarity of the directions on the tests $(M=4.00, S D=.97)$. Somehow agreement is also expressed with the issue concerning being informed about the evaluation criteria before the exams $(M=3.90, S D=.93)$, correct measurement of the language skills (writing $(M=3.77, S D=.73)$, reading $(M=3.62, S D=$ $.90)$, listening $(M=3.58, S D=.99)$ and speaking $(M=3.48, S D=1.03))$. It seems that students expressed comparatively less agreement for the correct measurement of speaking skills in comparison to other skills. As to the issue regarding test results being representative of students' actual performance, it is apparent that students have some concerns as none of the average means exceeded 3.50 in each specific language skill and in English in general, which would mean that students are closer to the not sure end in terms of this issue. Respondents almost agreed on their performance in the $\mathrm{MC}(M=3.80, S D=.89)$, the feedback received about their performances in the lessons $(M=3.64, S D=.91)$ and also in the exams $(M=3.55$, $S D=.95)$. However, the degree of agreement is less in the feedback in the exam results in comparison to this in the lessons. Related to their performance in the MC, respondents agreed on their language skills being improved after this course with the writing skills exhibiting the highest degree of improvement $(M=4.00, S D=.73)$ and the listening the least degree of improvement $(M=3.71, S D=.86)$.

When the students were asked to evaluate the effectiveness of each measurement tools in the course, they identified pop quizzes as the most effective assessment tool $(M=4.16, S D=.73$; see Table 10) and the oral quiz the less effective one $(M=3.90, S D=.92)$. However, given the means on the all assessment tools of the MC, it would be meaningful to conclude that students agreed on the effectiveness of all of the assessment procedures. 
A Program Evaluation Study of the Main Course at a Preparatory Program:

A Case Study

Table 10

Students' Opinions about the MC Assessment Tools

\begin{tabular}{lccccccc}
\hline & SA & A & NS & D & SD & $M$ & $S D$ \\
\hline Pop quizzez & $10(32.3)$ & $17(54.8)$ & $3(9.7)$ & $1(3.2)$ & - & 4.16 & .73 \\
Common quizzez & $9(29)$ & $15(48.4)$ & $7(22.6)$ & - & - & 4.06 & .73 \\
Class participation & $10(32.3)$ & $13(41.9)$ & $8(25.8)$ & - & - & 4.06 & .77 \\
Midterms & $6(20)$ & $16(53.3)$ & $7(23.3)$ & $1(3.3)$ & - & 3.90 & .76 \\
Final exams & $9(30)$ & $11(36.7)$ & $10(33.3)$ & - & - & 3.97 & .81 \\
Oral quizzez & $8(26.7)$ & $13(43.3)$ & $8(26.7)$ & $1(3.3)$ & - & 3.90 & .92
\end{tabular}

*Note. SA: Strongly agree / A: Agree / NS: Not sure / D: Disagree / SD: Strongly disagree *Note. $f(\%)$

In in the interviews, when the teachers were asked about the correct measurement of the language skills, three of the teachers responded their concerns with the testing of grammar. One of these teachers said the following:

"I have doubts about the relevance what is taught and what is tested. I am not an expert in that area, but should check it. For example, we try to teach the grammar contextually, that is, in a contextualized way. However, in the exams, we asked such questions that require rote-memorization and decontextualized sentences. Moreover, now that we have an integrated-skills course, we need to have a balance between the language skills. However, in the exams half of the paper is prepared for grammar testing, and the remaining half is given to the testing of all language skills. If meaning is more important than the form, why is it so?" (Teacher B)

When students were interviewed if the assessment procedures reflected their real performance, half of the students reported that they were happy about the assessment tools. The remaining half, however, mentioned their concerns with the measurement of speaking in that they believe that they did not reflect their actual performance, and their in-class performance are usually better than the exam performance. In order to have a little more concrete proof of the effect of the course on students' performance, all the results of one class on each and every examination tool was examined, and their mean scores on the three midterm exams and a final exam, among the common quizzes themselves were compared. Given the means from the three midterms 
with the final exam mean score, it appears that there is a descending trend in the scores towards the end of the year (see Figure 2 and Figure 3).

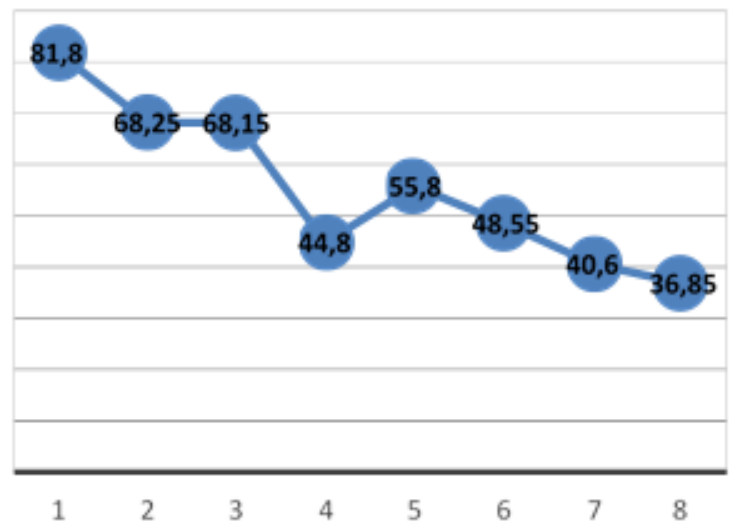

Figure 2. Comparison of the results on the means for common quizzes $(1,2,3,4,5,6,7 \& 8)$ as assessment tools

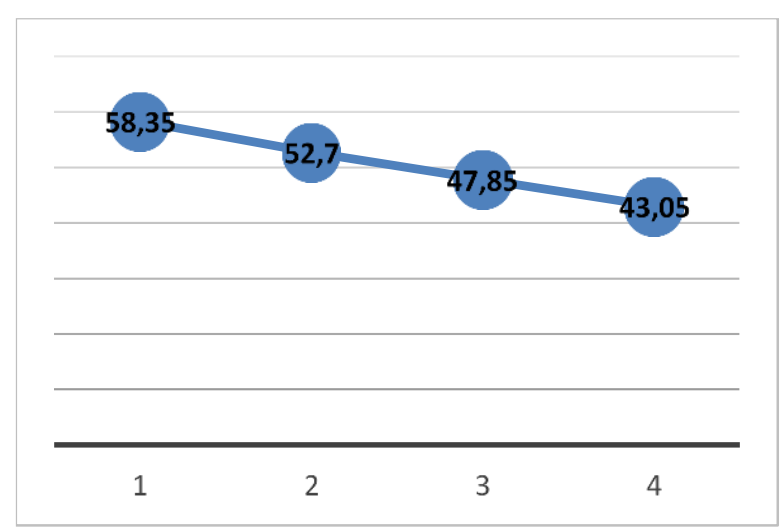

Figure 3. comparison of the results on the means for midterms (1, $2 \& 3)$ and final (4) as assessment tools

RQ3: What can be done to improve and strengthen the MC in terms of its four fundamental aspects, aims and objectives, course content and materials, course conduct and student assessment and outcomes?

\section{Course Aims and Objectives}

When students were asked to specify what other skills they would like to have been developed in the MC, they suggested that the course should aim at providing more practice skills with everyday language, more practice with speaking and listening skills and also with 
A Program Evaluation Study of the Main Course at a Preparatory Program:

A Case Study

pronunciation, more strategies for learning vocabulary, the need for the language use (as compared to language forms). The incorporation of target language culture within the course objectives was another recurring theme according to the interview data. One of the students pointed out this need by saying: "There should be some culture in the MC as it would be difficult to separate language from the culture. Therefore, MC may aim to give some knowledge on the target culture".

In the interviews, all three MC instructors suggested that some objectives concerning reading strategies and the integration of technology to the MC. Given the teachers' other recommendations, teachers insistently stated that next year they should revise the objectives, and set objectives before they choose the book so that they will have objectives independent of the course book. These teachers also made a suggestion in terms of adding objectives concerning students' developing individual study skills (through technology use) so that they could work individually and thus practice more. Other than the reading objectives, teachers also reported some revisions as to the grammar objectives in the form of adding some objectives about the contextual use of grammar. In this essence, one teacher stated "Students should be able to practice the same grammar pattern in more than one context".

\section{Course Content and Materials}

When the students were asked to suggest changes in relation to topics/themes, skills taught and the materials used, most of the students seemed happy with what they had in the MC as content and materials. However, rather than suggesting major changes, the students opted to suggest more practice opportunities with the course content. In terms of the inclusions regarding the course materials, students stated that more videos, presentation and discussion activities, more listening materials (CDs) should be used in this course. In the interviews, when students were asked to suggest topic/themes and also skills that could be incorporated to the MC, several students added that the presentation and research skills should be more emphasized in this course. 


\section{Course Conduct}

Given the responses of the students to the course evaluation questionnaire regarding how frequently they would like the listed activities and methods to be used in the MC, it is seen that video sessions, teacher correction of mistakes, questioning by the teacher, computer-aided activities, teacher correction of the mistakes were the most desired methods by the students (see Table 11). Group work, tape/CD listening, games and teacher lecturing were also highly suggested to be used in the MC by the students. It is also seen that assignments, students' doing self-correction and peer correction, individual silent study and student peer evaluation were comparatively less desired methods for use in the MC. Given the mean scores of the questionnaire respondents on the methods items, it is seen from the Table 11 below that several items (teacher correction of the students' mistakes $(M=2.50, S D=.51)$, video sessions $(M=$ $2.56, S D=.50)$, teacher lecture $(M=2.56, S D=.50)$ and pair work $(M=2.53, S D=.62)$ were preferred more compared to the others. Students' preferred frequency of use of the listed methods shows a direction from sometimes to frequently though mean values point out a need for sometimes frequency of use for the majority of the items on the list.

Table 11

Activities and Methods Students Would Like to be Used in MC

\begin{tabular}{|c|c|c|c|c|c|}
\hline & 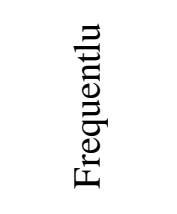 & 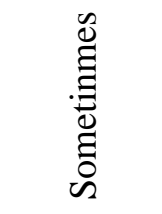 & $\begin{array}{l}\overline{\mathbf{D}} \\
\stackrel{0}{0}\end{array}$ & $M$ & $S D$ \\
\hline Teacher questioning & $16(50)$ & $15(46.9)$ & $1(3.1)$ & 2.47 & .57 \\
\hline Teacher lecture & $14(43.8$ & $18(56.3)$ & - & 2.56 & .50 \\
\hline Assignment/Homework & $7(23.3)$ & $19(63.3)$ & $4(13.3)$ & 2.10 & .61 \\
\hline Teacher correction of mistakes & $16(50)$ & $16(50)$ & - & 2.50 & .51 \\
\hline Computer-aided activities & $16(3.1)$ & $15(46.9)$ & $1(3.1)$ & 2.47 & .58 \\
\hline Pair work & $16(50.00)$ & $14(43.8)$ & $1(3.1)$ & 2.53 & .62 \\
\hline Group work & $15(46.9)$ & $13(40.6)$ & $3(9.4)$ & 2.48 & .71 \\
\hline Reading aloud by students & $10(31.3)$ & $19(59.4)$ & $3(9.4)$ & 2.22 & .61 \\
\hline Tape/CD listening & $15(48.4)$ & $14(45.2)$ & $2(6.5)$ & 2.42 & .62 \\
\hline Reading aloud by teachers & $12(37.5)$ & $18(56.3)$ & $2(6.3)$ & 2.31 & .59 \\
\hline Video sessions & $18(43.8)$ & $14(56.3)$ & - & 2.56 & .50 \\
\hline Student self-correction & $9(28.1)$ & $21(65.6)$ & $2(6.3)$ & 2.22 & .55 \\
\hline
\end{tabular}


A Program Evaluation Study of the Main Course at a Preparatory Program:

A Case Study

\begin{tabular}{|c|c|c|c|c|c|}
\hline & 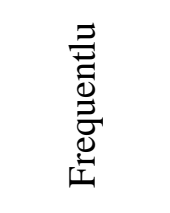 & 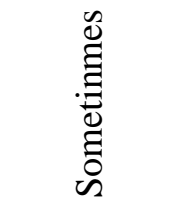 & $\begin{array}{l}\overline{0} \\
\overrightarrow{0} \\
z\end{array}$ & $M$ & $S D$ \\
\hline Student presentations & $10(31.3)$ & $20(62.5)$ & $2(6.3)$ & 2.25 & .58 \\
\hline Student self-evaluation & $8(25.0)$ & $21(65.6)$ & $3(9.4)$ & 2.16 & .57 \\
\hline Student peer-correction & $4(12.5)$ & $24(75.00)$ & $2(6.3)$ & 2.07 & .45 \\
\hline Translation & $12(37.5)$ & $17(53.1)$ & $13(9.4)$ & 2.28 & .63 \\
\hline Individual silent study & $6(18.8)$ & $23(71.9)$ & $3(9.4)$ & 2.09 & .53 \\
\hline Discussion & $11(34.4)$ & $17(53.1)$ & $3(9.4)$ & 2.31 & .69 \\
\hline Projects & $10(31.3)$ & $18(56.3)$ & $4(12.5)$ & 2.19 & .64 \\
\hline Role-plays & $11(34.4)$ & $17(53.1)$ & $4(12.5)$ & 2.22 & .66 \\
\hline Student peer evaluation & $7(21.9)$ & $18(56.3)$ & $7(21.9)$ & 2.00 & .67 \\
\hline Games & $14(43.8)$ & $14(43.8)$ & $4(9.4)$ & 2.41 & .71 \\
\hline Songs & $11(34.5)$ & $18(56.3)$ & $3(9.4)$ & 2.25 & .62 \\
\hline
\end{tabular}

For the question concerning the desired teacher behavior in the open-ended part of the questionnaire, most students agreed that their teachers are already doing well, and others recommended that the teacher should provide more opportunities for students to practice, force students to do the tasks and assignments, provide more fun opportunities like games, films and activities, behave more sensitively and also friendly towards the students and individual care for the students of different proficiency levels. Given the desired student behavior, while most says nothing, others suggested more opinion sharing and discussions among peers, peers being a model with their good use of grammar and pronunciation, students' speaking only in English and students behaving more disciplined in the class time.

For the question "How should teaching-learning process be in MC so that it would help the students a lot?" in the open-ended part of the questionnaire, students recommended a decrease in the class hours, having more variety of tasks and activities so as to make the class fun, more film watching activities and students performing more actively in the lessons. Basically, it appears that students desire a more practice and fun-based teaching learning process. Some of the students argued that the activities done in MC were sufficient and they suggested no other 
activities, while the remaining suggested including presentations, more video viewing and more discussion activities in teaching-learning process.

\section{Student Assessment and Course Outcomes}

For the question "How else your language skills (including all) could be better measured in the MC?", some students provided suggestions such as giving more listening tests and more careful marking of students' essays. In the interviews, one of the students said she is not that knowledgeable about how the students' performance should be measured, but she is happy with the system in the MC, whereas some students suggested that in-class performance should be taken into consideration more in the assessment of the students. Given the assignments, respondents recommend that teachers should force the students to finish and work on the assignments.

Two of the teachers recommended that the grammar should be tested in the way it has been taught. If the book is teaching grammar contextually, it is not appropriate to test grammar in isolated sentences; therefore, the teachers should revise their exam questions especially in relation to grammar.

\section{Discussion of the Results}

In relation to the evaluation of the aims and objectives of the $\mathrm{MC}$, both the teachers and the students of the MC evaluated the realization (their perceived fulfillment) of the existing MC objectives positively. It is also seen that speaking strategies were reported to be fulfilled by most of the students, which has been also supported by one of the teachers. There is also consistency on the realization of the listening objectives between the questionnaire results showing a comparably lower mean for the meeting of listening expectations and what one student reported with the comparably slower development of the listening skills. There are concerns over the objectives of grammar, and this is reflected in what one of the teachers wish to include new grammar objectives and the questionnaire results for the grammar objectives being the least realized skills objectives among others. For the testing or actualization of 
A Program Evaluation Study of the Main Course at a Preparatory Program:

A Case Study

grammar goals, Prabhu (1987) reported similar concerns especially for the testability of the realization of the objectives related to grammar in the famous Bangalore Project.

With respect to the materials, both the MC teachers and the students were generally happy with the materials used in the course with the textbook being the most favored one in the questionnaire and the interview results. It is important to note that students reported their satisfaction with the handouts prepared or provided by the teachers. Both the students and teachers also had an agreement about the ineffectiveness of the grammar book and the need for students' practice. However, it seems that the teachers attribute the lack of practice to irresponsible student behaviors, whereas the students to the lack of varied activities, skills and tasks. Erozan (2005) reported consistent results in relation to the absence of various types of class activities in the undergraduate EFL teacher program.

MC students generally evaluated the teaching-learning process positively in that, as shown by the questionnaire results, the teacher was helpful, encouraging of student participation, and there was a good student-teacher interaction. It also appears from the most frequent class methods and activities that the teachers are more active than the students, which has been also confirmed with the teacher interviews. This is also evident with the least used activities (songs, games, student peer evaluation, role-plays and projects and methods of the classroom. Likewise, in Yel's (2009), Erozan's (2005) and Öner and Mede's (2015) studies, students frequently reported the need for the presence of varied types of activities.

The results from the student evaluation questionnaire reveal that majority of the students had positive opinions about the effectiveness of the assessment procedures. It was indicated that students also agree to some extend with the correct measurement of the skills in the MC; but, it is striking that the least agreed-on skills in terms of its being correctly measured is speaking. In the questionnaires, the highest degree of improvement in the language skills was reported with the writing skills and the lowest with the listening skills, which has been also supported with the insights from the teacher and student interviews. Similarly, Sharp (1990) also reported that students experienced problems with their listening skills development in his evaluation of a four-month English course aiming to upgrade the English level of students for entering a university faculty. In the same vein, the results of Yel's (2009) evaluation for the English high 
school curricula revealed students' needs that are related to reading and writing skills were met more than their listening and speaking skills. Oral quizzes have been reported to be the least effective assessment tools by the students when compared to other skills, and this finding is consistent with the opinion that speaking skills being the least agreed-on skills among the students in terms of its being correctly measured. With respect to the exam scores and their comparison, it seems that there is a decrease in student performance from the beginning towards the end of the semester. A probable explanation for this gap may be the existence of a gap between what is taught and what is tested as also put forth by one of the MC instructors and documented in the exam papers examined by the researcher. Such a gap was also found by Yel (2009) in that the students reported assessment procedures as non-congruent with the course objectives.

\section{Suggestions for the Current MC}

In the light of the results of the current study, the following recommendations are made for the improvement of the MC.

1. Conducting needs assessment should be an important and inevitable component of the future MC design procedures. Information gathered from the needs assessment might be used in the determination of course aims and objectives, in the selection of the content and materials, in the selection of classroom activities and in also designing assessment tools.

2. Variety of tasks and activities (discussions, role-plays, debates, projects etc.) that will provide opportunities for the students to be more active in the classroom should be offered.

3. There should be more practice opportunities for the students in the teachinglearning process.

4. Listening skills should be emphasized and practiced more in the teaching-learning practice.

5. There should be in-service training sessions for the MC teachers which will provide training on the alternative assessment methods and techniques.

6. The grammar book chosen for this year should be changed in line with the expectations and requirements of the students. 
A Program Evaluation Study of the Main Course at a Preparatory Program:

\section{A Case Study}

7. Various sources of information should be taken into consideration for the course assessment. As suggested by the students, their in-class speaking performance should be incorporated to their final performance grade in speaking.

8. For the reported communication problems for the MC team teachers, forming a MC committee or coordinating office are recommended, and the MC committee should be responsible for the a) determination of the common methods and activities to be used in the teaching-learning process, b) determination of the assessment procedures to be employed, c) determination of the content to be taught or if needed the adaptations or supplementations to the book. For the sake of following the same standards, the committee should prepare set of guidelines or information on each of the three components above.

9. Reading strategies or strategic reading should be incorporated to the course content, and vocabulary exercises and learning strategies should accompany them.

10. Students should be guided, trained and monitored for the use of the internet tools provided to them so that they develop their study skills.

11. Students should be provided with more contexts so that they could see and practice a grammar point in another context, which, in turn, develop their use of language. New context opportunities (in reading passages) should be incorporated to the current course content.

12. There should be a relationship and consistency between the teaching and testing procedures.

\section{Suggestions for Future Evaluation Studies}

The evaluation model used in the current study is a flexible one. It could be used to evaluate a program at the macro level, or a course at the micro level. It could be even adapted to evaluate only one of the four focus areas. Using the adaptation performed for the purposes of this study, a further study may use the model with another discipline area course. 
The same study could be performed by including a more quantitative data for the outcomes dimension of the current study. This will add to the value of evaluation in that the researchers could present the effect of program on students' learning. The effect of the course or program on learning is of perhaps the most important issue in the educational settings as adding to students' cognitive student outcomes are often regarded as the preliminary duty of a course or a school system. 
A Program Evaluation Study of the Main Course at a Preparatory Program:

A Case Study

\section{References}

Bellon, J. J., \& Handler, J. R. (1982). Curriculum development and evaluation: A design for improvement. Dubuque, Iowa: Kendall/Hunt Publishing Company.

Beretta, A. (1992). Evaluation of language education: An overview . In J. C. Alderson \& A. Beretta, (Eds.), Evaluating Second Language Education (pp. 5-24). Cambridge, UK: Cambridge University Press.

Brown, H. D. (2007). Teaching by principles: An interactive approach to language pedagogy (3rd ed.). New York: Pearson Education.

Erozan, F. (2005). Evaluating the language improvement courses in the undergraduate ELT curriculum at Eastern Mediterranean University: A case study (Unpublished doctoral dissertation). Middle East Technical University, Ankara.

Erdem, H. E. (1999). Evaluating the English language curriculum at a private school in Ankara: A case study (Unpublished doctoral dissertation). Middle East Technical University, Ankara.

Keating, R.F. (1963). A Study of the Effectiveness of Language Laboratories (Keating Report).

New York: Institute of Administrative Research, Teachers College, Columbia University.

Mackay, R. (1998). Program evaluation and quality control. TESL Canada Journal, 17(2), 3342.

Mitchell, R., McIntyre, D., MacDonald, M., \& McLennan, S. (1987). Report of an Independent Evaluation of the Western Isles Bilingual Education Project. University of Stirling.

Morse, J. M. (1991). Approaches to qualitative-quantitative methodological triangulation. Nursing Research, 40(2), 120-123.

Norris, J. M. (Ed.). (2009). Understanding and improving language education through program evaluation [Special issue]. Language Teaching Research, 13,1-13.

Öner, G. \& Mede, E. (2015). Evaluation of A1 level program at an English preparatory school in a Turkish university: a case study. ELT Research Journal, 4(3), 204-226.

Patton, M. (2002). Qualitative research and evaluation methods (3rd ed.). Thousand Oaks:CA: Sage Publications. 
Prabhu, N. S. (1987). Second language pedagogy. Oxford: Oxford University Press.

Scherer, G. A., \& Wertheimer, M. (1964). A psycholinguistic experiment in foreign-language teaching. Columbus, $\mathrm{OH}$ : McGraw-Hill.

Scriven, M. (1967). The methodology of evaluation. In R. W. Tyler, R. M. Gagné, \& M. Scriven (Eds.), Perspectives of Curriculum Evaluation (pp. 39-83). Chicago: Rand McNally.

Sharp, A. (1990). Staff/student participation in course evaluation: A procedure for improving course design. ELT Journal, 44(2), 132-137.

Smith, P. D. (1970). A comparison of the cognitive and audiolingual approaches to foreign language instruction: The Pennsylvania foreign language project. Center of Curriculum Development Incorporated.

Stufflebeam, D. L. (1972). The relevance of the CIPP evaluation model for educational accountability. SRIS Quarterly, 5(1).

Tyler, R. W. (1949). Basic principles of curriculum and instruction. Chicago: University of Chicago Press.

Walberg, H., \& Haertel, G. (Eds.) (1990). The international encyclopedia of educational evaluation. Oxford: Pergamon.

Yel, A. (2009). Evaluation of the effectiveness of English courses in Sivas Anatolian High Schools (Unpublished master's thesis). Middle East Technical University, Ankara. 